\title{
Lysenin, a Sphingomyelin-Binding Protein: its Role in the Activation of Platelets
}

\author{
Kazuhiko Haruta ${ }^{1,2}$, Shigeto KobnYashi, Michiko Tajma ${ }^{1,3}$, Ryogo YUI $^{2}$, Naoto TAmura ${ }^{1}$, Isao Nagaoka ${ }^{3}$ and \\ Hiroshi Hashimoto!' \\ ${ }^{1}$ Department of Rheumatology and Internal Medicine and 'Department of Biochemistry, Juntendo University, School of Medicine, 2-1- \\ 1 Hongo, Bunkyo-ku, Tokyo 113-8421, Japan \\ ${ }^{2}$ Research Laboratory, Zenyaku Kogyo Co. Ltd., 2-33-7 Ohizumi-machi, Nerima-ku, Tokyo 178-0062, Japan
}

(Received 18 August 2002; and accepted 13 September 2002)

\begin{abstract} the mechanisms of the platelet activation.

Lysenin is a novel protein of $33 \mathrm{kDa}$ isolated from the earthworm, Eisenia foetida (24) and it binds specifically to sphingomyelin (SM) among the phospholipids located in the cell membrane (33): It has lethal effects on the mammalian red blood cells (RBC) and spermatogonia $(12,14,33)$, whose outer leaflets of their cell membranes are rich in SM com-
\end{abstract}

Lysenin is a novel protein of $33 \mathrm{kDa}$ isolated from the earthworm, Eisenia foetida, and it binds specifically to sphingomyelin (SM) among the phospholipids located in the cell membrane. Since it is known that SM is rich in the cell membrane of platelets', we evaluated the effects of lysenin on platelets. Flow cytometric analysis revealed that lysenin bound to platelets in a concentration dependent manner $(1-100 \mathrm{ng} / \mathrm{mL})$. Moreover, lysenin $(1 \mu \mathrm{g} / \mathrm{mL})$ induced irreversible aggregations of platelets with formation of thromboxane $\mathrm{B}_{2}$. The expressions of P-selectin and platelet endothelial cell adhesion molecule-1 (PECAM-1) on the surface of platelets were increased 5 min after the incubation of platelets with lysenin $(10-100 \mathrm{ng} / \mathrm{mL})$. These results indicate that SM in the cell membrane is involved in activation of platelets by lysenin. Lysenin might be a useful tool for studying

Abbreviations: SM, sphingomyelin; PECAM-1, platelet endothelial cell adhesion molecule-1; RBC, red blood cell; PGE, prostaglandin E; SMase, sphingomyelinase; $\mathrm{PE}$, phycoerythrin; BSA, bovine serum albumin; $\mathrm{PFA}$, paraformaldehyde; $\mathrm{PB}$, phosphate buffer; TXB, thromboxane $\mathrm{B}_{2}$; ELISA, enzyme-linked immunosorbent assay; CMC, carboxymethylcellulose; MFI, mean fluorescence intensity.

Corresponding to: Dr. Kazuhiko Haruta,

Research Laboratory, Zenyaku Kogyo Co. Ltd.,

2-33-7 Ohizumi-machi, Nerima-ku, Tokyo 178-0062, Japan

Tel: 03-3922-5131 Fax: 03-3922-5065

e-mail: Kazuhiko_Haruta@mail.zenyaku.co.jp sil:

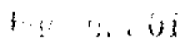

?

sij

pared with the inner leaflets $(22,29)$. It appears that the cell membranes of both RBC and spermatogonia are damaged by either perturbing the lipid layer structure or by forming aqueous pores induced by binding of lysenin to SM in their cell membrane $(14,33)$. Since the cell membrane of platelets contains SM at higher levels in the outer leaflets than the inner leaflet, as well as in the RBC (5), it is assumed that lysenin binds to SM in the platelet cell membrane and causes some effects on the platelet. In the present study, the effects of lysenin on platelets, aggregation of platelets, formation of thromboxane $\mathrm{B}_{2}$ and expression of cell adhesion molecules ( $\mathrm{P}-$ selectin and PECAM-1), which are requisite for the homophilic and heterophilic aggregation $(13 ; 15,18$, $20,27,31$ ), were analyzed to determine the mechanism of platelet activation.

\section{MATERIALS AND METHODS}

Animals. Female BALB/c mice (8 weeks of age, $18^{-}$ $20 \mathrm{~g}$ in weight) were purchased from Charles River 
Japan Inc. (Kanagawa, Japan). They were maintained at around $22^{\circ} \mathrm{C}$ with $12 \mathrm{~h}$ light/dark cycle and given a standard chow and tap water ad libitum.

Reagents. Lysenin and polyclonal rabbit anti-lysenin antiserum were purchased from Peptide Institute (Osaka, Japan). Prostaglandin E (PGE) and sphingomyelinase (SMase) from Bacillus cereus were purchased from Sigma Chemical (St. Louis, MO, USA). Diclofenac was purchased from Wako Pure Chemical (Osaka, Japan). Multilamellar liposome vesicles (SM-liposome) containing $1 \mathrm{mM} \mathrm{SM}$ and $1 \mathrm{mM}$ cholesterol, mixed at a molar ratio of $1: 1$ were kindly prepared by Dr. A. Yamaji (33). The anti-PECAM-1 monoclonal antibodies (BBIGP1, Seikagaku Corp, Tokyo, Japan), anti-P-selectin monoclonal antibodies (G1/G1-4, Ancell Corp. Bayport, MN, USA), phycoerythrin (PE)-conjugated goat anti-rabbit IgG (Southern Biotech. Assoc. Inc., Birmingham, AL, USA), and PE-conjugated goat anti-mouse IgG (Immunotech, Marseilles, France) were used for flow cytometry evaluation.

Preparation of platelets. Venous blood from healthy subjects was drawn with polypropylene syringe containing $3.8 \%$ sodium citrate (one tenth of blood volume) : and centrifuged at $100 \times g$ for $15 \mathrm{~min}$ to obtain the platelet-rich plasma. Next the platelets were sedimented by centrifugation at $2,000 \times g$ for $10 \mathrm{~min}$ and washed twice with $10 \mathrm{~mL}$ of Hepes-Tyrode buffer $(4 \mathrm{mM}$ Hepes, $1 \mathrm{mM} \mathrm{MgCl}, 130 \mathrm{mM}$ $\mathrm{NaCl}, 3 \mathrm{mM} \mathrm{KCl}$, and $5 \mathrm{mM}$ glucose, $0.35 \% \mathrm{BSA}$, $\mathrm{pH} 6.4)$ in the presence of PGE $(1 \mu \mathrm{g} / \mathrm{mL})$. After that, the platelets were resuspended in Hepes-Tyrode buffer (pH 7.4).

Binding of lysenin to platelets. Isolated platelets were treated with ice-cold $1 \%$ paraformaldehyde (PFA) in PBS to prevent activation of platelets. It has been reported that PFA-treatment dose not inhibit the binding of lysenin to SM in the cell membrane $(16,33)$. After washing with Hepes-Tyrode buffer, the platelets $\left(1 \times 10^{6}\right.$ cells $\left./ 100 \mu \mathrm{L}\right)$ were incubated with various concentrations of lysenin for $30 \mathrm{~min}$ at $4^{\circ} \mathrm{C}$. After washing with Hepes-Tyrode buffer, platelets were incubated with anti-lysenin antiserum $(1: 1,000)$ followed by incubation with PEconjugated goat anti-rabbit IgG $(1: 1,000)$ for 30 $\min$ at $4^{\circ} \mathrm{C}$. The fluorescence intensity of the cells $(5,000$ cells/experimental group) was analyzed with flow cytometry using FACStar (Becton Dickinson Immunocytometry Systems, San Jose, CA).
Specificity of binding of lysenin to SM in platelets cell membrane. To verify specific binding of lysenin to $\mathrm{SM}$ in the cell membrane, lysenin $(100 \mathrm{ng} / \mathrm{mL})$ preincubated with SM-liposome $(200 \mu \mathrm{M})$ for 30 $\min$ at $37^{\circ} \mathrm{C}$ was used. Moreover, the binding of lysenin to the platelet cell membrane, in which SM was digested by SMase was evaluated. For this purpose, platelets $\left(1 \times 10^{6}\right.$ cells $\left./ 100 \mu \mathrm{L}\right)$ were suspended in Hepes-Tyrode buffer without BSA, and incubated with SMase $(1 \mathrm{mUnit} / \mathrm{mL})$ for $30 \mathrm{~min}$ at $37^{\circ} \mathrm{C}$. After treatment with $1 \%$ PFA, the binding of lysenin $(100 \mathrm{ng} / \mathrm{mL})$ to platelets treated with SMase was analyzed with flow cytometry.

Platelets aggregation. Aggregation of platelets was measured by turbidimetric method with the aggregometor (NBS Hema Tracer 601, Niko Bioscience Inc., Tokyo, Japan) after addition of lysenin $(1 \mu \mathrm{g} / \mathrm{mL})$ to the platelet suspension in the presence of $1 \mathrm{mM} \mathrm{CaCl}_{2}$.

Scanning electron microscopy (SEM). After the incubation of platelets $\left(1 \times 10^{8}\right.$ cells $\left./ \mathrm{mL}\right)$ with $1 \mu \mathrm{g} / \mathrm{mL}$ of lysenin in the presence of $1 \mathrm{mM} \mathrm{CaCl}$ for $3 \mathrm{~min}$ at $37^{\circ} \mathrm{C}$, the platelets were fixed with $10 \mathrm{~mL}$ of $4 \%$ PFA in phosphate buffer (PB, pH 6.7) for 30 min at $4{ }^{\circ} \mathrm{C}$. After centrifugation at $2,000 \times \mathrm{g}$ for $10 \mathrm{~min}$, sedimented platelets were post-fixed with $100 \mu \mathrm{L}$ of $5 \%$ glutaraldehyde in $0.15 \mathrm{M} \mathrm{PB}(\mathrm{pH}$ 6.7) for 30 min. The platelets were then washed with $0.15 \mathrm{M}$ PB and mounted on cover slides coated with poly-Llysin $(10 \mu \mathrm{g} / \mathrm{mL})$. After dehydration in graded ethanol series and replacement of ethanol with isoamyl acetate, the platelets were dried with a critical point dryer (HCP2, Hitachi, Tokyo Japan), sputtered with platinum-palladium, and examined under scanning electron microscopy (S-800, Hitachi).

Formation of thromboxane $B_{2}$. Isolated platelets (1 $\times 10^{8}$ cells $/ \mathrm{mL}$ ) were incubated with lysenin in the presence of $1 \mathrm{mM} \mathrm{CaCl}$. The reaction was terminated by adding indomethacin $(10 \mu \mathrm{g} / \mathrm{mL})$ at $5 \mathrm{~min}$ after incubation of platelets treated with lysenin. The amount of thromboxane $\mathrm{B}_{2}$ (TXB) in the culture supernatant was determined using TXB immunoassay kit (R\&D system Inc., Minneapolis, MN, USA). The enzyme-linked immunosorbent assay (ELISA) procedures were conducted according to the manufacture's instructions.

Expression of P-selectin and PECAM-1 in platelets. Isolated platelets $\left(1 \times 10^{6}\right.$ cells $\left./ 100 \mu \mathrm{L}\right)$ were incubated with lysenin $(1,10,100 \mathrm{ng} / \mathrm{mL})$ in a $\mathrm{CO}_{2}$ incu- 
bator for $5 \mathrm{~min}$ in the presence of $1 \mathrm{mM} \mathrm{CaCl} 2$ or 30 min in the absence of $\mathrm{CaCl}_{2}$. The cells were then treated with $1 \%$ PFA, and washed twice with HepesTyrode buffer ( $\mathrm{pH}$ 7.4). The cells were stained for $30 \mathrm{~min}$ with a saturated concentration of anti-P-selectin monoclonal antibodies $(1: 100)$ or the antiPECAM-1 monoclonal antibodies $(1: 1,000)$ diluted with Hepes-Tyrode buffer, followed by reaction with PE-conjugated goat anti-mouse $\operatorname{IgG}(1: 100)$ for 30 min. Thereafter, the fluorescence intensity of the cells $(10,000$ cells/experimental group) was analyzed with flow cytometry.

Effects of lysenin on platelets in vivo. We determined the effects of diclofenac on survival time after injection of a lethal dose of lysenin, since diclofenac is known to inhibit the activation of platelets (7). Diclofenac suspended in 1\% carboxymethylcellulose (CMC) was administered intraperitoneally $30 \mathrm{~min}$ prior to intravenous administration of lysenin $(60 \mu \mathrm{g} / \mathrm{kg})$. These experiments were conducted with authorization of the Animal Care and Use Committee at the Research Laboratory of Zenyaku Kogyo Co. Ltd.

Statistical analysis. Statistical analyses were conducted utilizing the Mann-Whitney's U test for nonparametrical data in the experiments for effects of diclofenac on the survival time after injection of lysenin. $\mathrm{P}$ values of less than 0.05 were considered statistically significant.

\section{RESULTS}

\section{Binding of lysenin to platelets}

Flow cytometric analysis revealed that lysenin bound to the surface membrane of the platelet in a concentration dependent manner $(1-100 \mathrm{ng} / \mathrm{mL}$, Fig. 1). Lysenin $(100 \mathrm{ng} / \mathrm{mL})$ bound to the PFAtreated platelet and the mean fluorescence intensity (MFI) was 647.9. However, it virtually diminished to MFI: 21.2 with the use of lysenin $(100 \mathrm{ng} / \mathrm{mL})$ preincubated with SM-liposomes. Next, we determined the binding of lysenin $(100 \mathrm{ng} / \mathrm{mL})$ to platelets, which had been treated with SMase. There was no shift in fluorescence intensity (MFI: 8.7), when the effects of lysenin on the platelets treated with SMase were evaluated, indicating a lack of lysenin bound to the platelets. These findings indicate that SM located in the platelet cell membrane is a requisite for binding of lysenin to the platelets.

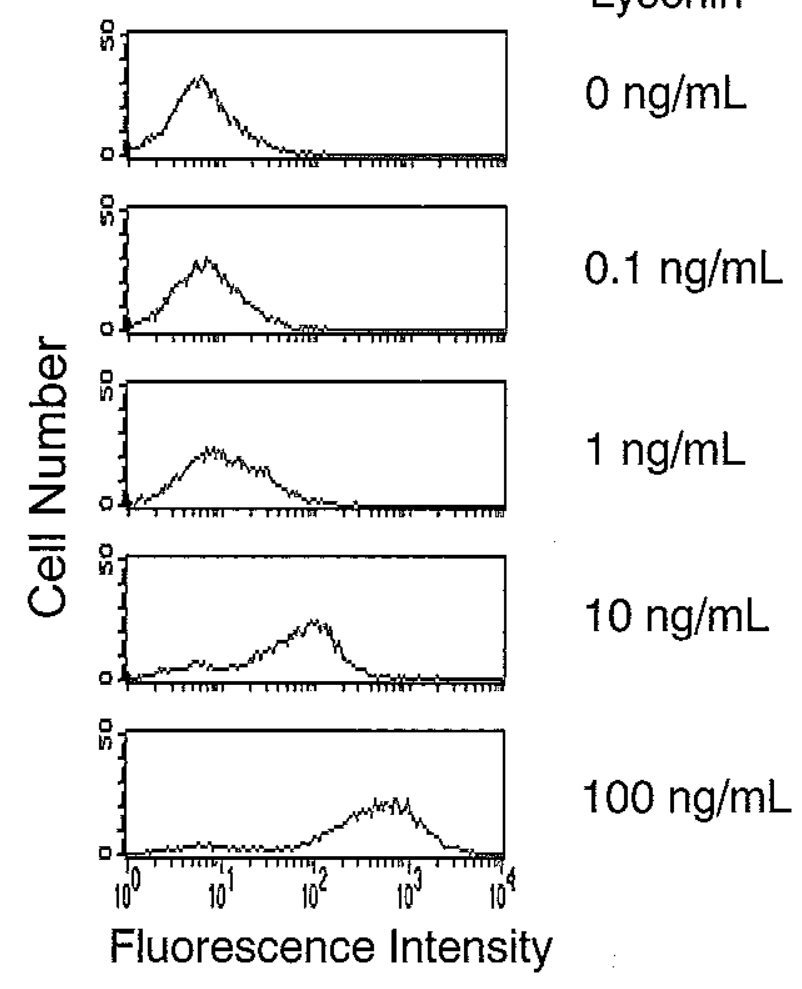

Fig. 1 Flow cytometric analysis of lysenin binding to platelets. Binding of lysenin to platelets after incubation of lysenin with platelets for $30 \mathrm{~min}$ at $4^{\circ} \mathrm{C}$. Lysenin bound to platelets in a concentration dependent manner $(1,10,100 \mathrm{ng} / \mathrm{mL})$.

Induction of aggregation of platelets by lysenin Addition of lysenin $(100 \mathrm{ng} / \mathrm{mL}$ or $1,000 \mathrm{ng} / \mathrm{mL})$ to platelet suspension resulted in an increase in light transmission. The level of light transmission reached a plateau $1 \mathrm{~min}$ after incubation of platelets with lysenin $(1,000 \mathrm{ng} / \mathrm{mL}$, Fig. 2 left $)$. Morphologically, the platelets $\left(1 \times 10^{8}\right.$ cells $\left./ \mathrm{mL}\right)$ incubated with lysenin $(1,000 \mathrm{ng} / \mathrm{mL})$ for $3 \mathrm{~min}$ were swollen, projected many long pseudopodia and aggregated (Fig. 2 right). Thus, lysenin $(1,000 \mathrm{ng} / \mathrm{mL})$ induced irreversible aggregation within $1 \mathrm{~min}$ after incubation.

Effects of lysenin on the formation of TXB, P-selectin and PECAM-1 expression in platelets.

The formation of TXB by platelets increased in a concentration dependent manner $\left(10^{-} 1,000 \mathrm{ng} / \mathrm{mL}\right.$, Fig. 3). Moreover, flow cytometric analysis revealed that the expression of P-selectin on the surface of platelets was increased by incubation of platelets with 10 or $100 \mathrm{ng} / \mathrm{mL}$ of lysenin in the presence of $\mathrm{CaCl}_{2}$, but not in the absence of $\mathrm{CaCl}_{2}$ (Fig. 4a). On 

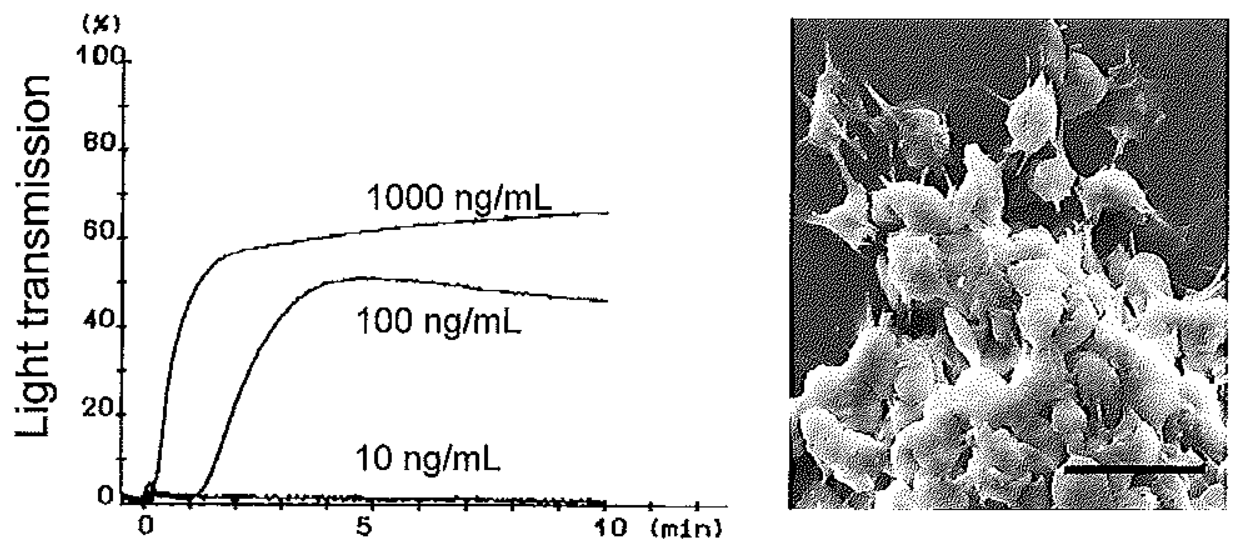

Fig. 2 Aggregation of platelets induced by lysenin. Light transmission reached its maximal level at $3 \mathrm{~min}$ after incubation of platelets with lysenin $(1,000 \mathrm{ng} / \mathrm{mL})$ in the presence of $1 \mathrm{mM} \mathrm{CaCl}(l e f t)$. Cells treated with lysenin $(1,000$ $\mathrm{ng} / \mathrm{mL}$ ) were swollen and projection of numerous long pseudopodia was confirmed (right). Scale: $5 \mu \mathrm{m}$.

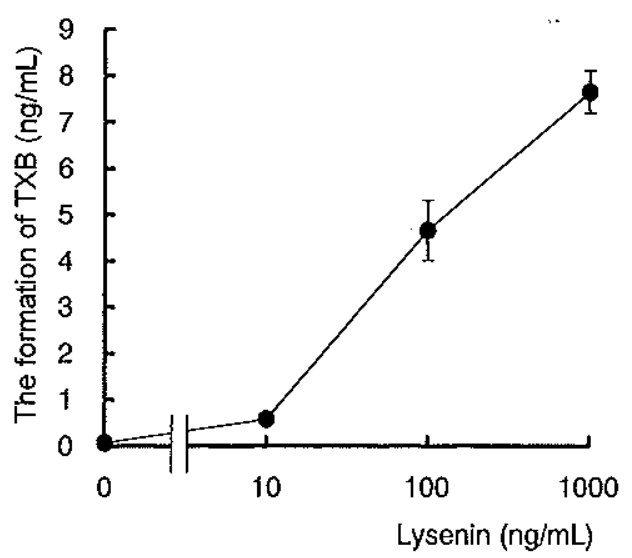

Fig. 3 Formation of TXB in platelet induced by lysenin. Platelets were incubated with lysenin for $5 \mathrm{~min}$ in the presence of $1 \mathrm{mM} \mathrm{CaCl}$. The formation of TXB was determined by ELISA. Each value is expressed as the mean \pm SD of data from three independent experiments.

the other hand, the expression of PECAM-1 on platelets increased in a concentration dependent manner by incubation of platelets with lysenin (10, $100 \mathrm{ng} / \mathrm{mL}$ ) for 5 min. This up-regulation of PECAM-1 expression induced by lysenin $(100$ $\mathrm{ng} / \mathrm{mL}$ ) was also revealed after incubation in the absence of $1 \mathrm{mM} \mathrm{CaCl}_{2}$ for $30 \mathrm{~min}$ (Fig. 4b). These results indicated that lysenin induced the degranulation in platelets which occurs along with the activation of platelets.

\section{Effects of lysenin on platelets in vivo}

In rats injected with lysenin $(15,30$ or $60 \mu \mathrm{g} / \mathrm{kg})$ into the tail vein, the doses above $30 \mu \mathrm{g} / \mathrm{kg}$ is re- ported to cause respiratory distress and death within $10 \mathrm{~min}$ after injection (24). In our study, lysenin (15, 30 or $60 \mu \mathrm{g} / \mathrm{kg}$ ) was intravenously injected into five mice. Mice injected intravenously with lysenin at 15 or $30 \mu \mathrm{g} / \mathrm{kg}$ did not die within one week after the injection. However, the injection of lysenin $(60 \mu \mathrm{g} / \mathrm{kg})$ induced respiratory distress and death within $10 \mathrm{~min}$ after injection. Then, we evaluated the effects of diclofenac on: the survival time after injection of lysenin $(60 \mu \mathrm{g} / \mathrm{kg})$. The survival time $(949.4 \pm 98.5$ $\mathrm{s} ; \mathrm{n}=5)$ of the mice treated with diclofenac $(150$ $\mathrm{mg} / \mathrm{kg}, i p)$ and lysenin $(60 \mu \mathrm{g} / \mathrm{kg})$ was significantly $(P<0.05)$ greater than that $(165.6 \pm 33.3 \mathrm{~s} ; \mathrm{n}=5)$ of mice receiving $1 \% \mathrm{CMC}$ and lysenin $(60 \mu \mathrm{g} / \mathrm{kg}$, Fig. 5). These findings indicate that lysenin induces the activation of platelets resulting in death.

\section{DISCUSSION}

Lysenin appears to bind to cell membrane of the platelets, as well as $\mathrm{RBC}$, spermatogonia, fibroblast and oligodendrocytes. The binding of lysenin to platelets diminished, when lysenin was preincubated with SM-liposomes. Furthermore, lysenin did not bind to the platelets pretreated with SMase. These results indicate that lysenin binds specifically to SM located in the cell membrane of platelets. The binding may be related to the morphological changes of the platelet cell surface as revealed by scanning electron microscopy. These results coincide with the findings that lysenin increased the formation of TXB in platelets and the expression of both P-selectin and PECAM-1 on the surface of the platelets. Thus, it is revealed that lysenin induced the activation of platelets. It is scientific merit to clarify the 
a. P- selectin

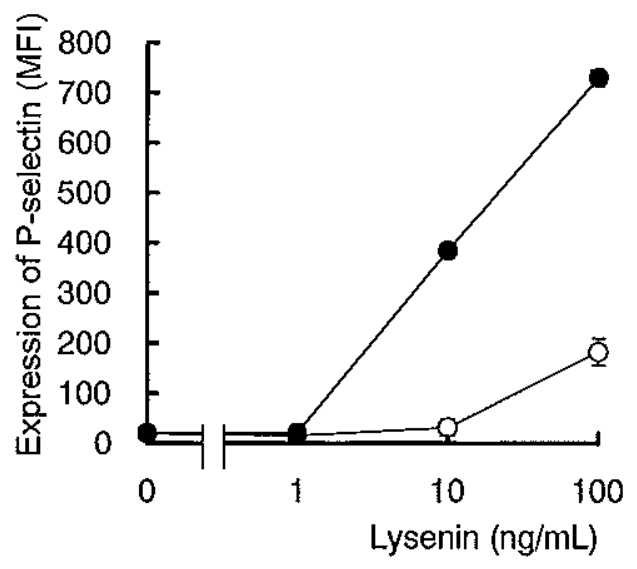

b. PECAM- 1

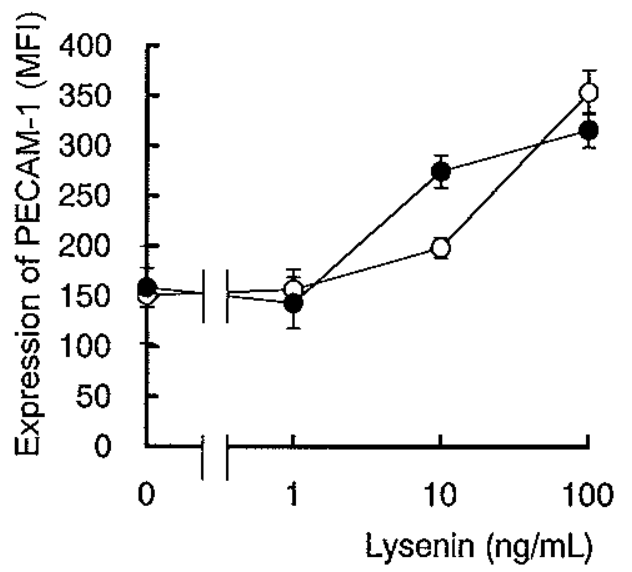

Fig. 4 The up-regulation of P-selectin and PECAM-1 expression on the platelets induced by lysenin. Platelets were incubated with lysenin for $5 \mathrm{~min}$ in the presence (closed circle) or $30 \mathrm{~min}$ in the absence (open circle) of $1 \mathrm{mM}$ $\mathrm{CaCl}_{2}$. The expressions of P-selectin (a) and PECAM-1 (b) were analyzed with flow cytometry. Each value is expressed as the mean \pm sD of data from three independent experiments. MFI: Mean fluorescence intensity.

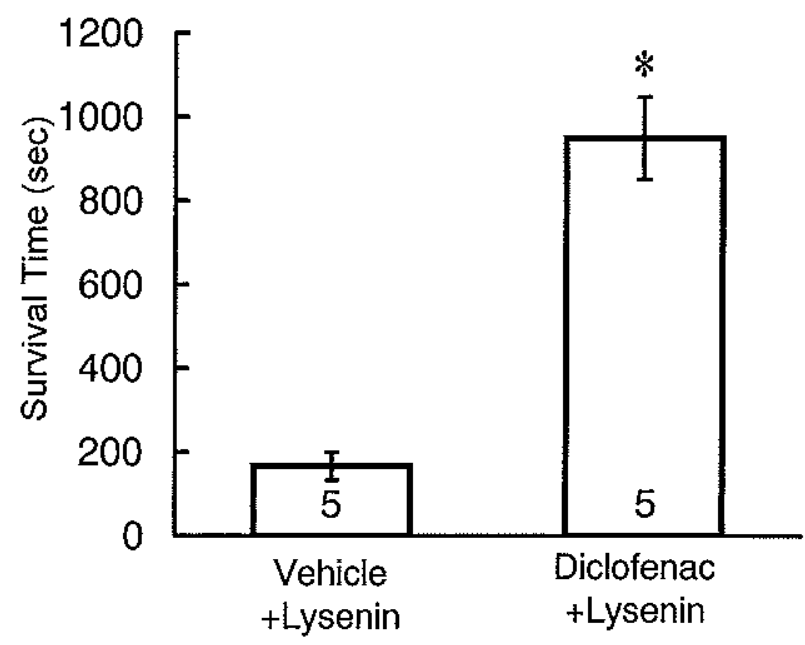

Fig. 5 Effect of diclofenac on the lethal effects of lysenin in mice. Survival time of mice injected with lysenin $(60 \mu \mathrm{g} / \mathrm{kg}, i v)$ was greater in the diclofenac (150 $\mathrm{mg} / \mathrm{kg}, i p)$-treated mice than control mice. Time of each group is expressed as the mean \pm SEM $(n=5)$. The number in each column indicates the number of mice. ${ }^{\circ} P<0.05$ (Mann-Whitney's U test).

mechanisms involved in the activation of platelets by lysenin. It is known that platelets are activated via receptors for thrombin or collagen, however, the amino acid sequence of lysenin has no homology to those of known proteins (25). Moreover, lysenin does not have the RGD sequence which induces the activation of platelets (32). Accordingly, lysenin appears to activate the platelets through a different mechanism from those of known activators. In other words, lysenin appears to activate the platelets in specific way: through its binding to SM located in the cell membrane.

Since SM inhibits activities of phosphatidylinositol phosphodiesterase and 12-lipoxygenase in platelets $(8,11), \mathrm{SM}$ is postulated to inhibit the activation of platelets. However, the involvement of SM in the activation of platelets remains obscure. There is a possibility that lysenin binds to SM resulting in the disruption of the lipid layer structure or forming aqueous pores in the cell membrane of platelets, and may induce colloid osmotic changes resulting in influx of $\mathrm{Ca}^{2+}$ into the platelets. The increase of intracellular $\mathrm{Ca}^{2 *}$ induces the activation of platelets (1). Another possibility is that lysenin may affect the "raft" which is SM and cholesterolrich microdomain located in the cell membrane. Specific proteins assemble in the rafts and play a role in signal transduction $(3,21,26)$. It has been reported that Src family kinase is associated with SM in rafts of platelets (30). Src family kinase is involved in the up-regulation of PECAM-1 expression on platelets and phosphorylation of PECAM-1, which is induced by thrombin or convulxin in the presence of EGTA, indomethacine and apyrase (6). In the present studies, the up-regulation of PECAM-1 expression on platelets was revealed after incubation with lysenin in the absence of $\mathrm{Ca}^{2+}$. Thus, it was suggested that the binding of lysenin to SM in the rafts may lead to the activation of the Src family kinase.

Activation of platelets is accompanied by an al- 
teration in the distribution of lipids located in the cell membrane (2). Negatively charged lipids like phosphatidylserine become exposed at the outer leaflets of cell membrane and facilitate the conversion of factor $\mathrm{X}$ to factor $\mathrm{Xa}$ by the factor IX-factor VIIIa and $\mathrm{Ca}^{2+}$ complex as well as conversion of prothrombin to thrombin by a complex factor XaFactor Va and $\mathrm{Ca}^{2+}(23,28)$. Lysenin induced the upregulation of $\mathrm{P}$-selectin expression on the platelets in this study. The binding of P-selectin to monocyte induces the up-regulation of tissue factor expression on the cell surface of monocyte (4). Tissue factor binds to factor VII and factor VIIa and activates factor IX and factor X (19). Thus, it was suggested that the activation of platelets by lysenin influences the blood coagulation factors as well as heterophilic and homophilic aggregation of platelets $(13,15,18,20$, 27,31 ) resulting in the formation of thrombosis in vivo. This suggestion was supported by the results that the lethal effects of lysenin were attenuated by diclofenac, which inhibited the activation of platelets.

Recently, it has been revealed that $\mathrm{C}$ type lectins from snake venom affect the function of collagen receptor on platelets $(9,17)$. However, the mechanism of platelets activation has not been fully clarified, therefore, research and development of a new reagent is required to solve the mechanism of platelets activation (10). In this study, we indicated that lysenin activated the platelets via binding to SM located in the cell membrane of platelets. Thus, lysenin may be an useful tool for determining the mechanism involved in platelet activation in relation to the cell membrane.

\section{Acknowledgement}

We gratefully acknowledge Dr. Hideshi Kobayashi, emeritus professor of University of Tokyo, for his valuable advice and help in conducting our experiments. This work was supported by The Research Committee on Intractable Vasculitis Syndrome, Surveys and Research on Specific Diseases, the Ministry of Health Labour and Welfare of Japan, 2001.

\section{REFERENCES}

1. Abrams C. S. and Brass L. F. (2000) Platelets signal transduction. In: Hemostasis and thrombosis. Basic principles and clinical practice 4th ed. Colman R. W, Hirsh J, Marder V. J, Clowes A. W, George J. N, eds. Philadelphia; Lippincott Williams and Wilkins.

2. Bevers E. M., Comfurius P. and Zwaal R. F. (1983) Changes in membrane phospholipid distribution during platelet activa- tion. Biochim. Biophys. Acta 736, 57-66.

3. Brown D. A. and Lodon E. (2000) Structure and function of sphingolipid- and cholesterol-rich membrane rafts. J. Biol.Chem. 275, 17221-17224.

4. Celi A., Pellegrini G., Lorenzet R., De Blasi A., Ready N., Furie B. C. and Furie B. (1994) P-selectin induces the expression of tissue factor on monocytes. Proc. Natl. Acad. Sci. USA 91, 8767-8771.

5. Chap H. J., Zwaal R. F. A. and van Deenen L. L. M. (1977) Action of highly purified phospholipases on blood platelets. Biochim. Biophys. Acta 467, 146-164.

6. Cicmil M., Thomas J. M., Sage T., Barry F. A., Leduc M., Bon C. and Ginnins J. M. (2000) Collagen, convulxin, and thrombin stimulate aggregation-independent tyrosine phosphorylation of CD31 in platelets. J. Biol. Chem. 275, 2733927347.

7. Cronberg S., Wallimark E. and Sodeberg I. (1984) Effect on platelet aggregation of oral administration of 10 non-steroidal analgesics to humans. Scand. J. Haematol. 33, 155-159.

8. Dawson R. M. C., Hemington N. and Irvine R. F. (1985) The inhibition of diacylglycerol-stimulated intracellular phospholipases by phospholipids with a phosphocholine-containing polar group. A possible physiological role for sphingomyelin. Biochem. J. 230, 61-68.

9. Dormanm D., Clemetson J. M., Navdaev A., Kehrel B. E. and Clemetson K. J. (2001) Alboaggregin A activates platelets by a mechanism involving glycoprotein VI as well as glycoprotein Ib. Blood 97, 929-936.

10. Escolar G. and White J. G. (2000) Changes in glycoprotein expression after platelet activation: differences between in vitro and in vivo studies. Thromb. Haemost. 83, 371-386.

11. Fujimoto Y., Sakuma S., Tsunomori M., Sumiya T. and Fujita T. (1999) Sphingomyelin inhibits platelet 12-lipoxygenase activity. Eur. $J$. Pharmacol. 378, 233-236.

12. Ito M., Abe S., Sekizawa Y. and Kobayashi H. (1997) Lethal effects of lysenin, a novel protein isolated from the coelomic fluid of the earthworm Eisenia foetida, on the spermatozoa of African clawed frog and the mouse. Biomed. Res. 18, 399404.

13. Kansas G. S. (1996) Selectin and their ligands: Current component and controversies. Blood 88, 3259-3287.

14. Kobayashi H., Sekizawa Y., Aizu M. and Umeda M. (2000) Lethal and non-lethal responses of spermatozoa from wide variety of vertebrates and in vertebrates to lysenin, a protein from the coelomic fluid of the earthworm Eisenia foetida. $J$. Exp. Zool. 286, 538-549.

15. McEver R. P. and Cummings R. D. (1997) Role of PSGL-1 binding to selectins in leukocyte recruitment. J. Clin. Invest. 100, 485-492.

16. Nakai Y., Sakurai Y., Yamaji A., Asou H., Umeda M., Uemura $\mathrm{K}$. and Itoh K. (2000) Lysenin-sphingomyelin binding at the surface of oligodendrocyte lineage cells increases during differentiation in vitro. J. Neurosci. Res. 62, 521-529.

17. Navdaev A., Clemetson J. M., Polgar J., Kehrel B. E., Glauner M., Magnenat E., Wells T. N. and Clemetson K. J. (2001) Aggretin, a heterodimeric C-type lectin from Calloselasma rhodostoma (Malayan pit viper), stimulates platelets by binding to alpha $2 \beta 1$ integrin and glycoprotein $\mathrm{lb}$, activating Syk and phospholipase $\mathrm{C} \gamma 2$, but does not involve the glycoprotein VI/Fc receptor $\gamma$ chain collagen receptor. $J$. Biol. Chem. 276, 20882-20889.

18. Newman P. J. (1997) The biology of PECAM-1. J. Clin. Invest. 99, 3-8.

19. Osterud B. and Rapaport S. I. (1997) Activation of factor IX 
by the reaction product of tissue factor and factor VII: additional pathway for initiating blood coagulation. Proc. Natl. Acad. Sci. USA 74, 5260-5264.

20. Palabrica T., Lobb R. and Furie B. C., Aronovits M., Benjamin C., Hsu Y. M., Sajer S. A. and Furie B. (1992) Leukocyte accumulation promoting fibrin deposition is mediated $i$ vivo by P-selectin on adherent platelets. Nature 387, 569-572.

21. Prieschl E. E. and Baumruker T. (2000) Sphingolipids: second messengers, mediators and rafts constituents in signaling. Immunol. Today 21, 555-560.

22. Rana A. P. S., Misra S., Majumder G. C. and Ghosh A. (1993) Phospholipid asymmetry of goat plasma membrane during epididymal maturation. Biochim. Biophys. Acta 1210, $1-7$.

23. Rosing J., Tans G, Govers-Riemslag J. W., Zwaal R. F. and Henker H. C. (1980) The role of phospholipids and factor Va in the prothrombinase complex. J. Biol. Chem. 255, 274-283.

24. Sekizawa Y., Hagiwara K., Nakajima T. and Kobayashi H. (1996) A novel protein, lysenin, that causes contraction of the isolated rat aorta: its purification from the coelomic fluid of the earthworm, Eisenia foetida. Biomed. Res. 17, 197-203.

25. Sekizawa Y., Kudo Y., Kobayashi H., Nakajima T. and Natori S. (1997) Molecular cloning of cDNA for lysenin, a novel protein in the earthworm Eisenia foetida that causes contraction of rat vascular smooth muscle. Gene 191, 97-102.

26. Simons K. and Ikonen E. (1997) Functional rafts in cell membrane. Nature 387, 569-572.

27. Sun J., WVilliams J., Yan H. C., Amin K. M., Albelda S. M. and DeLiseer H. M. (1996) Platelets endothelial cell adhesion molecule-1 (PECAM-1) homophilic adhesion is mediated by immunoglobulin-like domains 1 and 2 and dependents on the cytoplasmic domain and the level of surface expression. $J$. Biol. Chem. 271, 18561-18570.

28. Van Dieijen G., Tans G, Rosing J. and Hemker H. C. (1981) The role of phospholipids and factor VIIIa in the activation of bovine factor X. J. Biol. Chem. 256, 3433-3442.

29. Verkleij A. J., Zwaal R. F. A., Roelofsen B., Comfurius P., Kastelijn D. and van Deenen L. L. M. (1973) Asymmetric distribution of phospholipids in human red cell membrane. Biochim. Biophys. Acta 323, 178-193.

30. Waheel A. A., Shimada Y., Heijnen H. F. G., Nakamura M., Inomata M., Hayashi M., Iwashita S., Slot J. W. and OhnoIwashita Y. (2001) Selective binding of perfringolysin $O$ derivative to cholesterol-rich membrane microdomains (rafts). Proc. Natl. Acad. Sci. USA 98, 4926-4931.

31. Wu X. W. and Lian E. C. Y. (1997) Binding properties and inhibition of platelet aggregation by a monoclonal antibodies to CD31 (PECAM-1). Arterioscl. Thromb. Vas. Biol. 17, 31543158.

32. Yamada K. M. Adhesive recognition sequences. (1991) $J$. Biol. Chem. 266, 12809-12812.

33. Yamaji A., Sekizawa Y., Emoto K., Sakuraba H., Inoue K., Kobayashi H. and Umeda M. (1998) Lysenin, a novel sphingomyelin-specific binding protein. J. Biol. Chem. 273, $5300-5306$. 